\title{
Annual Report 1995
}

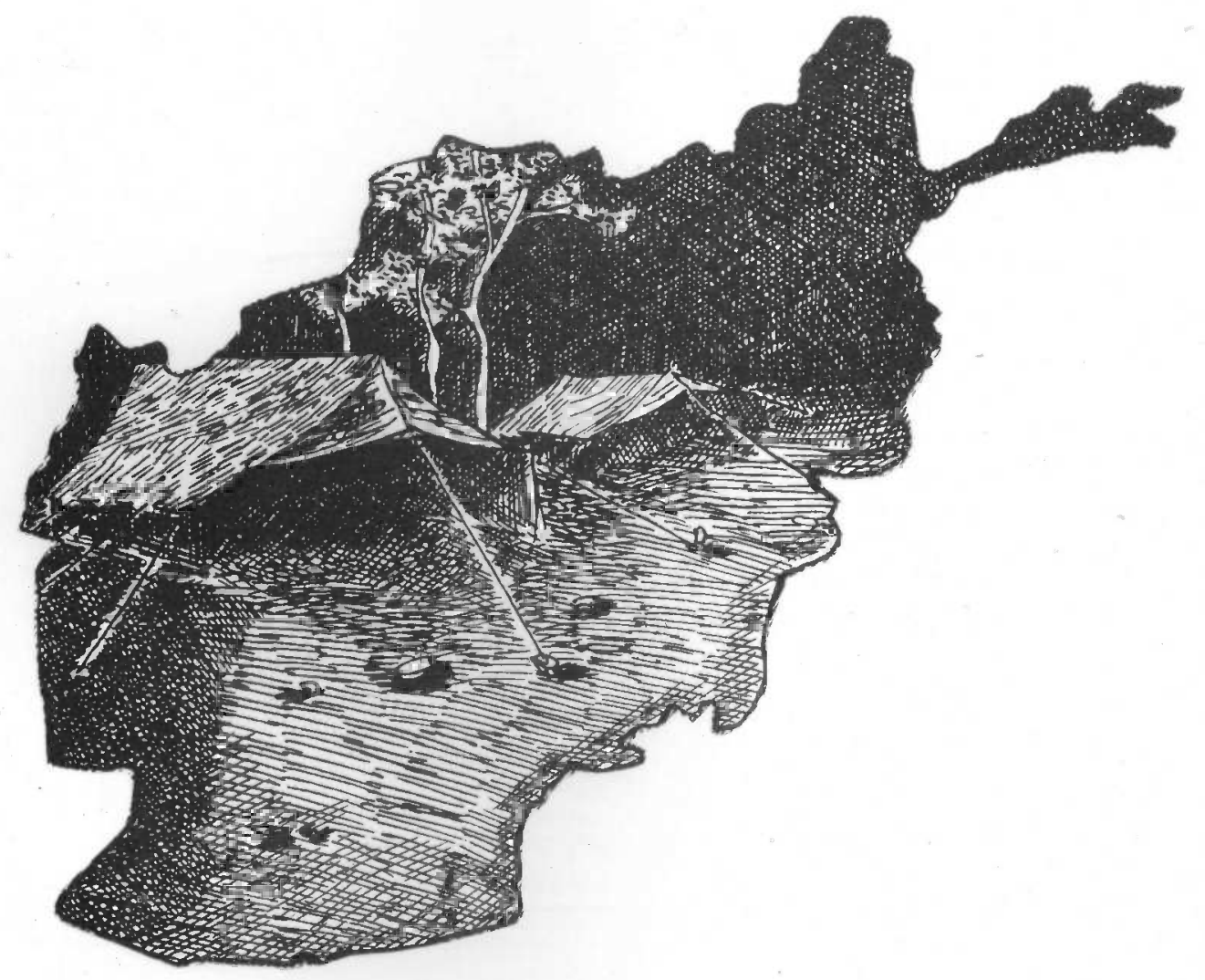

Norwegian Afghanistan
Committee 
Peshawar

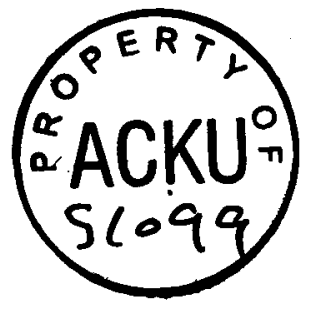




\section{INTRODUCTION}

As a consequence of nearly 17 years of civil war, daily tragedies such as rape, murder, raids and torture, made by militant guards and officials, make the Afghan civilians the main victim of a human right catastrophe. The tragedy is now largely ignored by the rest of the world although outside powers fuel the continuing disorder.

Once more, the battle over the city of Kabul, by the Afghan political factions and leaders led to enormous losses and humanitarian tragedies. Thousands of people left their homes and fled to Ghazni, Jalalabad and other peaceful areas where NAC provided some of them with food, health education and basic necessities.

While the factions were destroying the capital's human and material assets, people in the Afghan countryside, with the assistance of NGOs like NAC were quietly rebuilding their schools, water-supply systems and roads. NAC have also provided rural areas with health facilities, running of clinics, hospitals, vaccination and malaria control programs.

Many refugees still linger in Pakistan, held back from returning by security and economic concerns. NAC's educational services for refugees continued in 1995.

There are problems caused by poverty and corruption which have affected implementation of some of the programs this year, as well as the loss of one of the vehicles from the central office in Peshawar. 
The political radical changes by the Taliban in twelve of the twenty nine Afghan provinces during 1995 have to a certain extent brought betterment related to security in their controlled areas, but there is no doubt that the situation for girls and females has hardened. By introducing "Islamic laws" girls have been left out from the education system and Afghan female employees are no longer allowed to work outside their homes. Exceptions have been made for females working within the health sector.

Despite the discouraging backdrop for females living in Taliban ruled areas and the continuing battle over Kabul NAC believes it was successful in providing effective projects to encourage daily life in our programs areas.

$N A C$ sends its thanks to the many donors who made these programs a reality.

Eva Søure

Director

Peshawar 10 April 1996 


\section{ARTICLES OF THE ORGANIZATION}

1. NAC is an acronym for Norwegian Afghanistan Committee.

2.The objectives are:

- To participate in rehabilitation and development of the war devastated country.

- highest priority is to be given to rehabilitationy development projects and to emergency aid inside Afghanistan.

- the work shall be based on development of knowledge, mutual understanding and friendship between the Afghan and Norwegian péople.

3. Organizational structure:

- NAC is an apolitical, independent non governmental organization, with representation in Afghanistan, Pakistan and Norway.

- The organization is headed by a main office in Oslo, Norway.

- The activities in Afghanistan are structured into program areas, each'run by a Program Office which reports to the Central Office in Peshawar, Pakistan. 
- NAC has a steering board, composed of 11 members from the local committees in Norway. Annual member assembly is undertaken once a year.

5. Funds and auditing.

- Funds for the work are raised from members contribution, private and governmental sources.

- Once a year an account audit of the activities of the Committee shall be made.

\section{PERSONNEL}

The main resources for NAC's activities are the staff. None of our achievements would have been possible without the staffs' effort and hard work. This human resource will be further strengthened by increased emphasis on education and training in 1996. 
At the year end 1995, the NAC-staff in Afghanistan and Pakistan totalled 97 Afghans, 1 Pakistan and 3 expatriates.

\section{Badakhshan Ghazni Peshawar Total}

\begin{tabular}{lllll} 
Project workers & 22 & 14 & 3 & 39 \\
Administration & 4 & 3 & 2 & 9 \\
Logistic/ store & 5 & 3 & 2 & 10 \\
Accountant & 4 & 2 & 2 & 8 \\
Service staff & 12 & 10 & 13 & 35 \\
\hline Total & 47 & 32 & 22 & 101
\end{tabular}

Included in the Peshawar based staff are Eastern program project staff, education officer for the schools in Peshawar and the service staff for the expatriate residence. The number of administration staff includes 3 expatriates, of whom one left at the end of December 1995.

In addition to the above mentioned staff, approximately 2500 Afghan men and women were directly linked to different projects as teachers, health workers and casual laborers, employed to work within reconstruction of schools, clinics, water supply program, and road projects.

Three of NACs permanent staff employed in the program areas were terminated in 1995, due to irregularities. Three did not get their contrac ts renewed and eight resigned, of whom 5 were situated in Ghazni program area, 2 in Badakhshan, 1 Peshawar and one expatriate. 


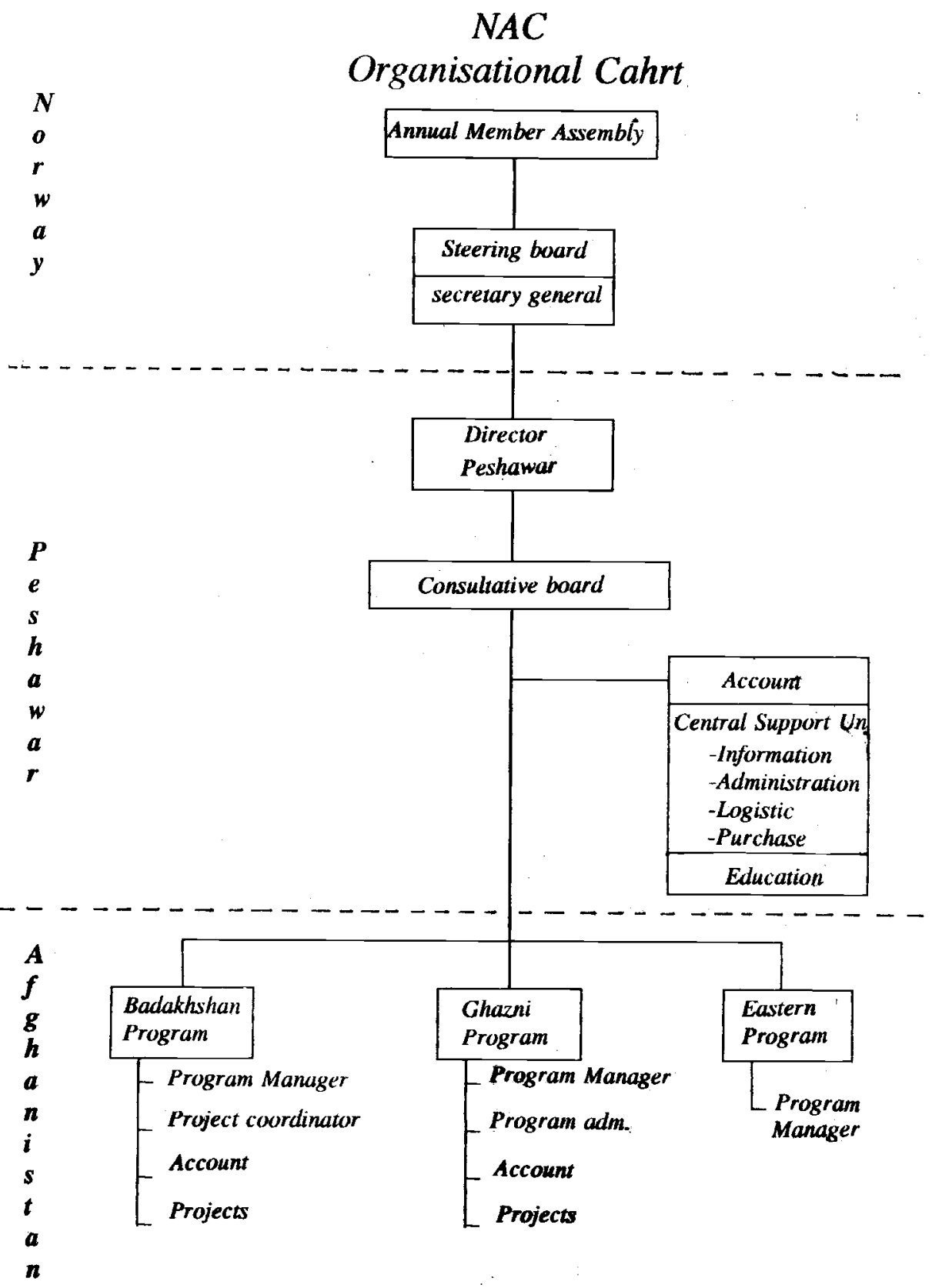




\section{THE POLITICAL SITUATION.}

In the beginning of 1995 the political picture of Afghanistan changed as an armed political group known as the Taliban (religious students) took control of several of Afghanistan provinces in February. The Talibans, many of whom received religious training in Islamic schools in Pakistan, emerged as a strong military and political force. In November 1994 they captured the city of Kandahar from Mujaheddin groups.

From Kandahar the Talibans advanced towards Ghazni. In early March 1995, the Talibans entered western part of Kabul district and disarmed Hezb-e-Wahdat militia who were in control of Karte Seh. President Rabbani forces attacked Karte Seh in middle of March, and the Taliban temporarily withdrew from the area.

During the spring and summer of 1995 the warring factions in Kabul calmed down, and daily life in the capitol became optimistic. Repatriation started and the resettlement increased until the Talibans once more launched attacks on the city of Kabul after capturing Herat in September 1995.

Throughout the autumn up to the year end fighting in the city of Kabul caused many civilian casualties and extensive damage to property and public facilities. Several thousands of people fled their homes once more, seeking refuge in the safer areas of Jalalabad and Ghazni. The humanitarian situation in the city of Kabul was further aggravated by several economic blockades.

Of Afghanistan 29 provinces the Talibans have taken control of 12. The largest number of provinces controlled by a single party.

(Reference-Political map). 
The following points should be mentioned as goals and factors influencing the rapid progress of Talibans:

- The civil war exhausted the inhabitants of the war torn country.

- Inhuman behavior of Islamic parties as well as previous commanders and armed Mujahedeen, disappointed the local people.

- Talibans provided security and collected arms from previously armed people.

- Talibans punished the criminals in their control areas according to Islamic law, which resulted in a decline of the crime rate, according to a Taliban spokesman.

- Taliban restore seized property and land of civilians in their control areas.

- Taliban promise to establish a broad based Islamic government in the country.

The political circumstances in Afghanistan are bewildering. Despite efforts made by the United Nations peace negotiator, Misteri, discussions with the Afghan leadership have failed. It seems there is still a long way to go for a complete peace solution in the country. 


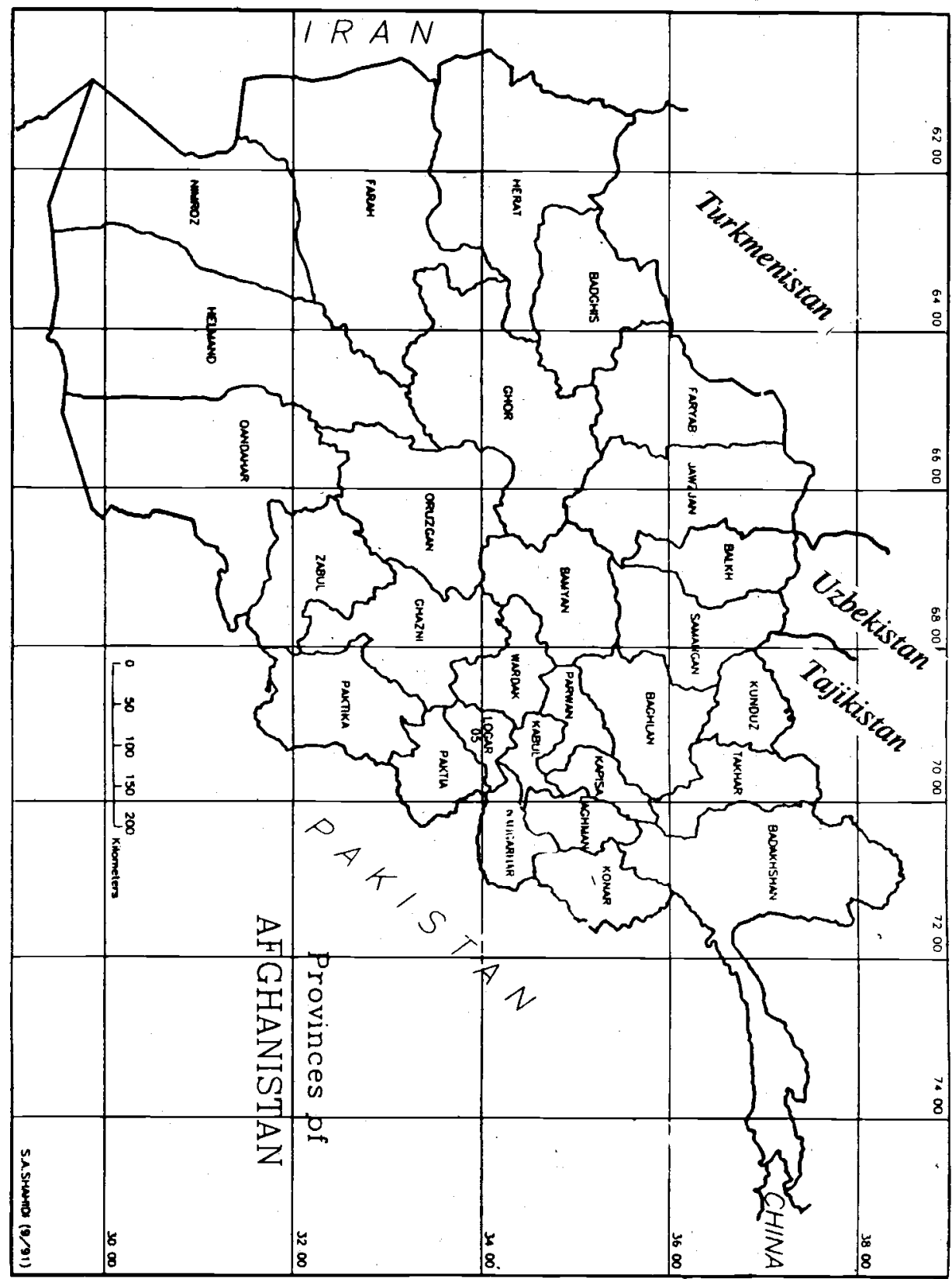


12

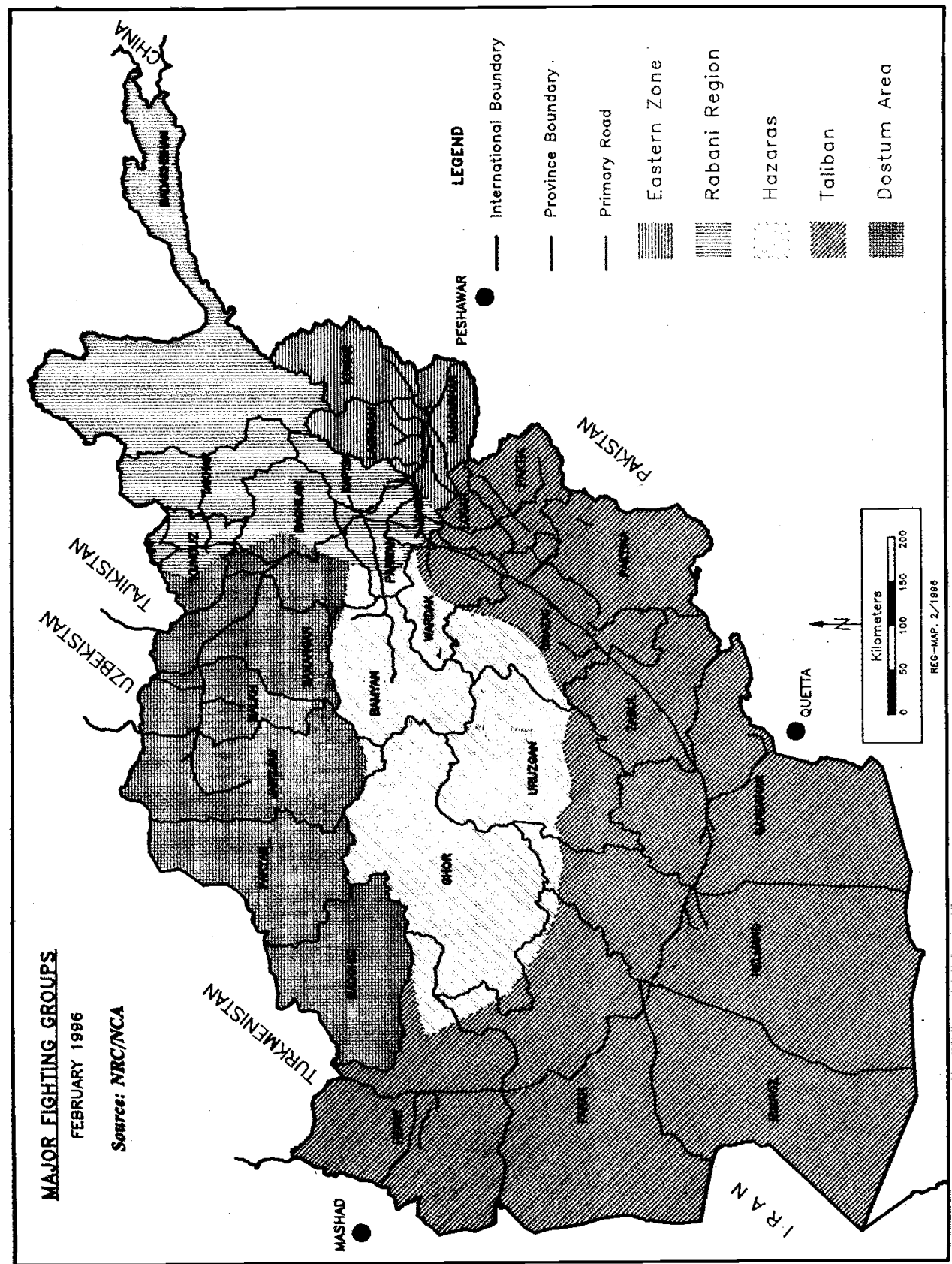




\section{ASSISTANCE WITHIN SECTORS.}

$N A C$ 's overall project philosophy is based on the idea of integrated rural development and rehabilitation to a limited number of areas in Afghanistan.

To improve the health situation for example, different aspects must be considered, such as access to clean water, level of education and information. Even rehabilitation of transport roads and communication are a necessity. It is impossible to confine the needs of an area to only one sector and NAC has continued a multi-sectorial approach.

\section{BADAKSHAN PROGRAM}

\section{General}

BADAKSHAN is the most north easterly province of Afghanistan; it borders Pakistan, Tajikistan and China and covers 47,000sq km. Much of the province is covered by hills and high mountains (up to $7000 \mathrm{~m}$ ) and dissected by deep valleys. Fertile land is scarce. Irrigable land is at a premium. The population is estimated to be between 500,000 to 600,000 persons. The bulk of the population is concentrated along the river valleys of the central and western areas of the province. During 1995 NAC implemented programs in Health, Agriculture, Reconstruction, School Improvement, Irrigation, Sanitation, Communication and Emergency sectors. 


\section{Badakhshan \& NAC Projects}

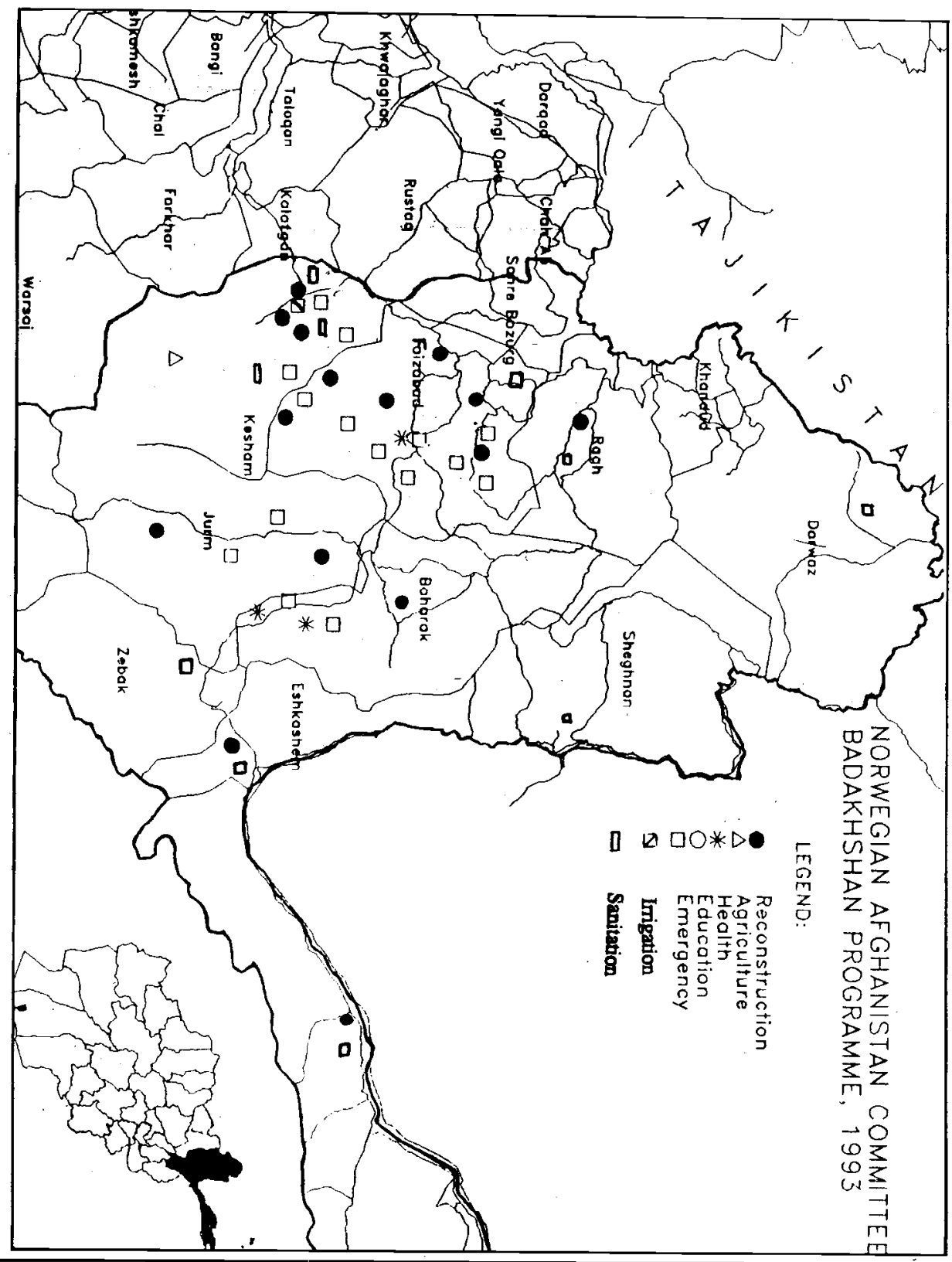




\section{Health}

During 1995 NAC distributed 2000 bednets in Keshem, Faizabad, Teshkan, Argu and Khombok Districts as a link in the malaria control program.

Donor:

MSF-HOLLAND/NORAD

\section{Health Infrastructure}

Three standard Health Clinics were built in Ragh, Shahr-I-Buzurg and Hazrat-I-Sayed. Each clinic has eleven rooms.

Donor: $\quad U D / S C A / W F P$

\section{Agriculture}

As part of the erosion control program seedlings were planted in the demonstration plot in Keshem town and in the nursery in Khumbok. The saplings produced at the nursery were taken for planting to the erosion control project in Khumbok, unfortunately due to lack of rain about $98 \%$ of the saplings planted died. To control the death of the saplings during 1996 a water pump should be taken to the project for watering.

Donor: $\quad U D$ 


\section{Education}

During 1995 NAC reconstructed and repaired a total number of 19 schools of which three admitted girl pupils. The standard NAC school designs of eight classrooms and four administration rooms were built and completed buildings were handed over to the Education Department of the Badakshan Government. One three roomed village school was also built, Atnjelow.

$\begin{array}{lllll}\text { School } & \text { Type } & \text { District } & \text { Work } & \text { Donor } \\ \text { Bazgeer } & \begin{array}{l}\text { Primary } \\ \text { boy/girl }\end{array} & \text { Eshkashem } & \text { Recon } & \text { SCA/UD/WFP } \\ \text { Shakarlab } & \begin{array}{l}\text { Primary } \\ \text { boy/girl }\end{array} & \text { Payan } & \text { Recon } & \text { NORAD/WFP } \\ \text { Cheta } & \text { High }{ }^{+} \text {pri } & \text { Faizabad } & \text { Recon } & \text { UD/SCA/WFP } \\ \text { Qarlogh } & \text { Primary } & \text { Dareyem } & \text { Recon } & \text { NORAD/UDWFP } \\ \text { Sarghelan } & \text { 6th grade } & \text { Zardew } & \text { Recon } & \text { NORAD/WFP } \\ \text { Kaib } & \text { High } & \text { Jurm } & \text { Repair } & \text { SCA/UD/WFP } \\ \text { Atinjelow } & \text { Primary } & \text { Argu } & \text { Recon } & \text { NORAD/WFP/UD } \\ \text { Khandood } & \text { Primary } & \text { Wakhan } & \text { Repair } & \text { UD/SCA/WFP }\end{array}$



5 schools High +pri
Keshem
Repair
$U D / W F P$
6 schools High + pri
Faizabad
Repaír
$U D / W F P$

Unfortunately two school repair programs in Ragh and Shahr Buzurg could not be undertaken as the community did not bring their local material contribution.

\section{Irrigation Infrastructure}

Two irrigation channels were completed. The Dasht-I-Shahidan channel which is one of the biggest irrigation channels in Keshem was completed. It had four components: repair of the intake, reconstruction of a superpassage on Takha Chook wash, construction of a retaining wall at the end part of an old government constructed super-passage, construction of a siphon on Abijeem gully and extension of $3 \mathrm{~km}$ of channel.

The Chilgaza channel also located in Keshem had an 88 meter long retaining wall constructed along the irrigation channel. This part of the channel used to collapse when the amount of water increased which had resulted in major problems for the community during the agricultural work season.

Donor: $\quad U D / W F P / S C A$ 


\section{Chetah School \\ Faizabad}

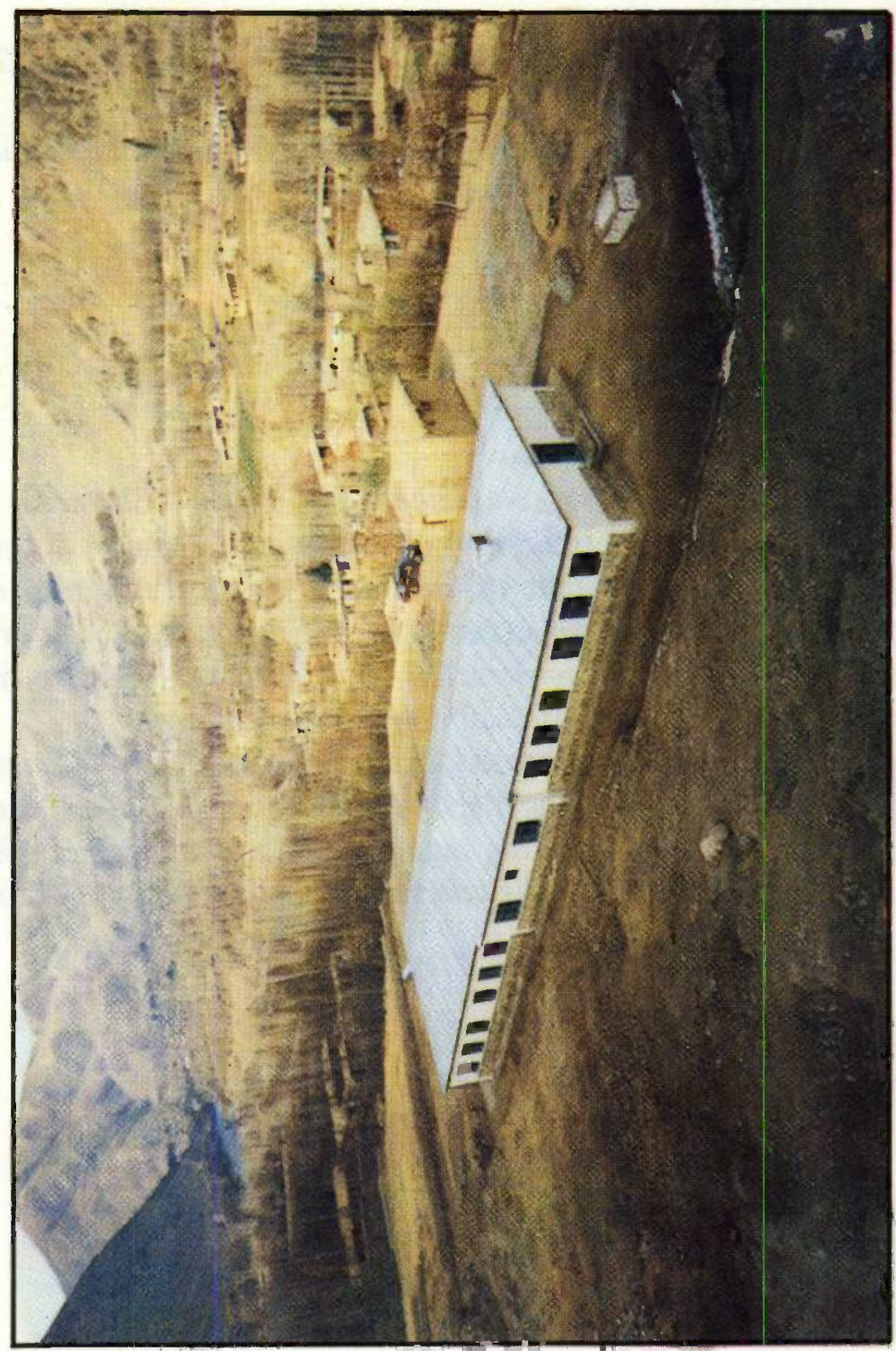




\section{Dasht-i-Shahidan channel Keshem}

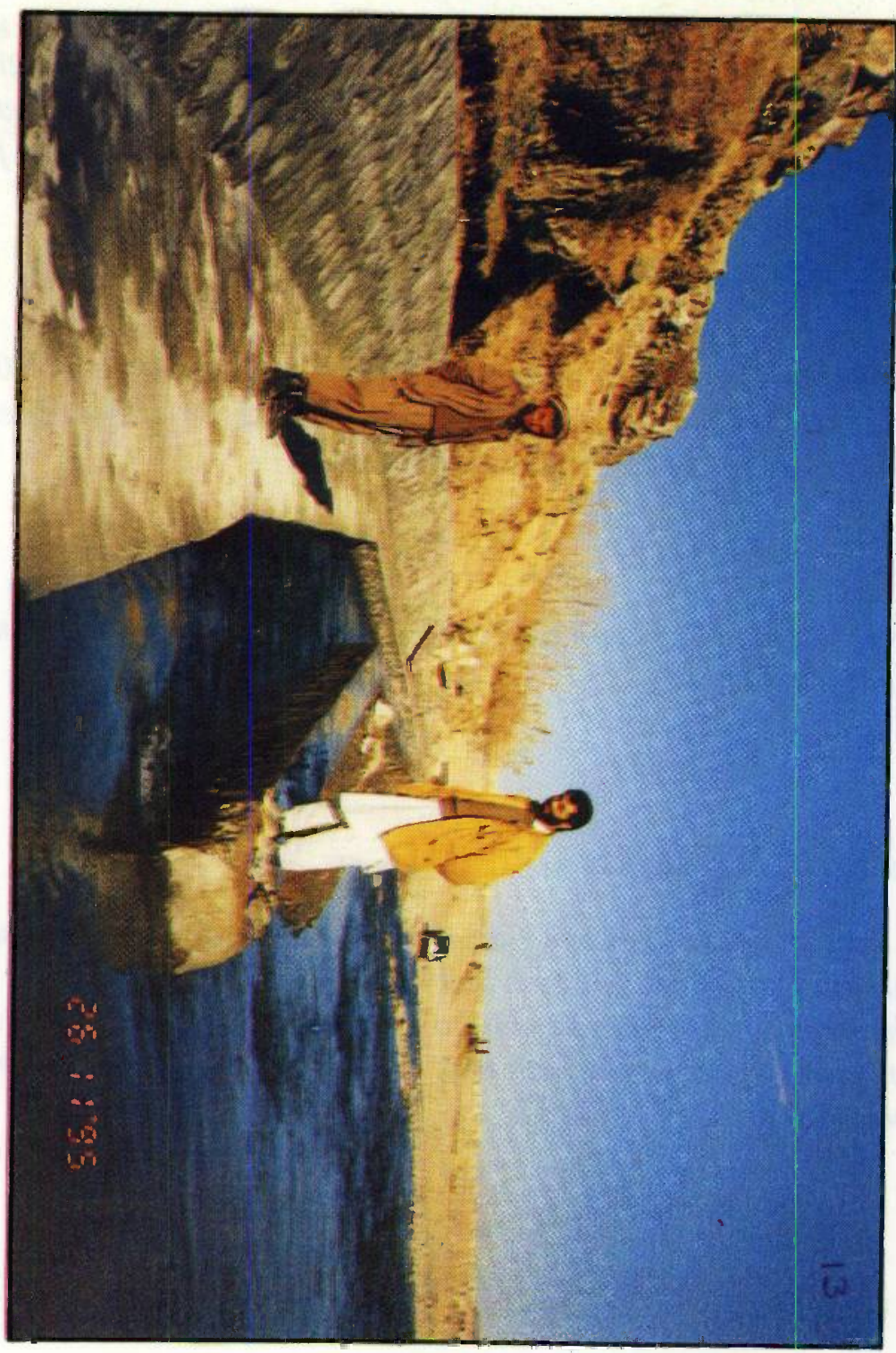




\section{Sanitation Infrastructure}

The Gandum Qol project consisted of three integrated components: a gravity fed water supply system, latrine slab production and health education for about 600 families resident in Gandum Qol. Two local plumbers were also trained for the future maintenance of the project. On completion the project was handed over to the local community.

Donor: $\quad$ UD/UNICEF/WFP

In Mohammed Aba village a water reservoir with a capacity of 40 cubic meters with three out let taps was constructed for use for 200 families. The project was handed over to the local community.

Donor:

NORAD/WFP

An improved latrine block with four cubicles was constructed for Namazgah school, Keshem.

Donor: $\quad$ NORAD/WFP

\section{Communication Infrastructure}

An $88 \mathrm{~km}$ long link road between Faizabad and Ragh district was opened in 1995. The road linked areas which had never seen a vehicle in there before. During the peak construction time 1600 laborers were working on the road. The major cost of the road which was labor wages was covered by WFP wheat donation.

Donor: $\quad U D / W F P$ 


\section{Ragh Road \\ Badakhshan}

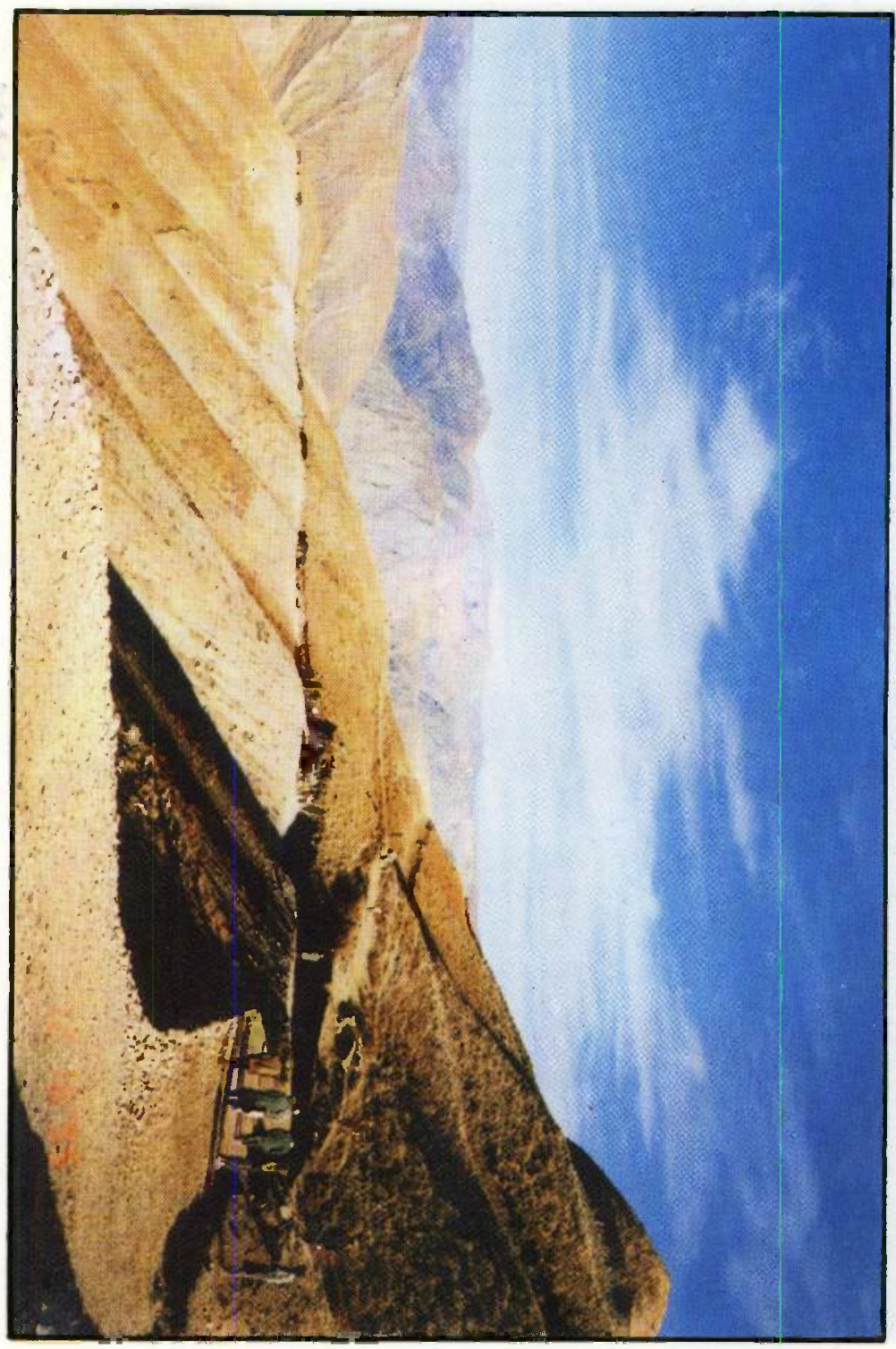




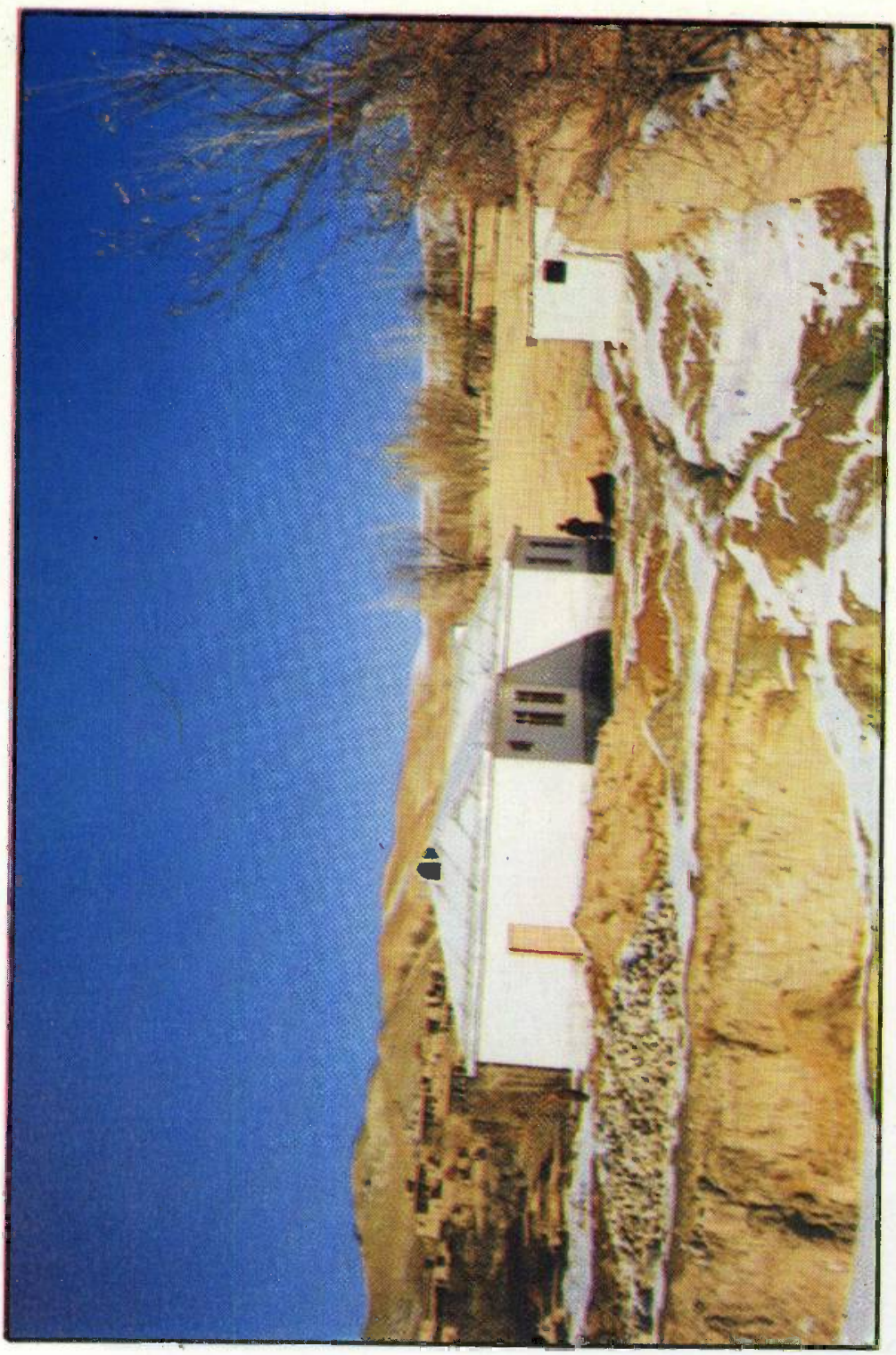

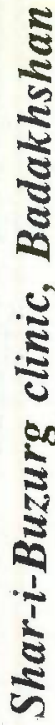




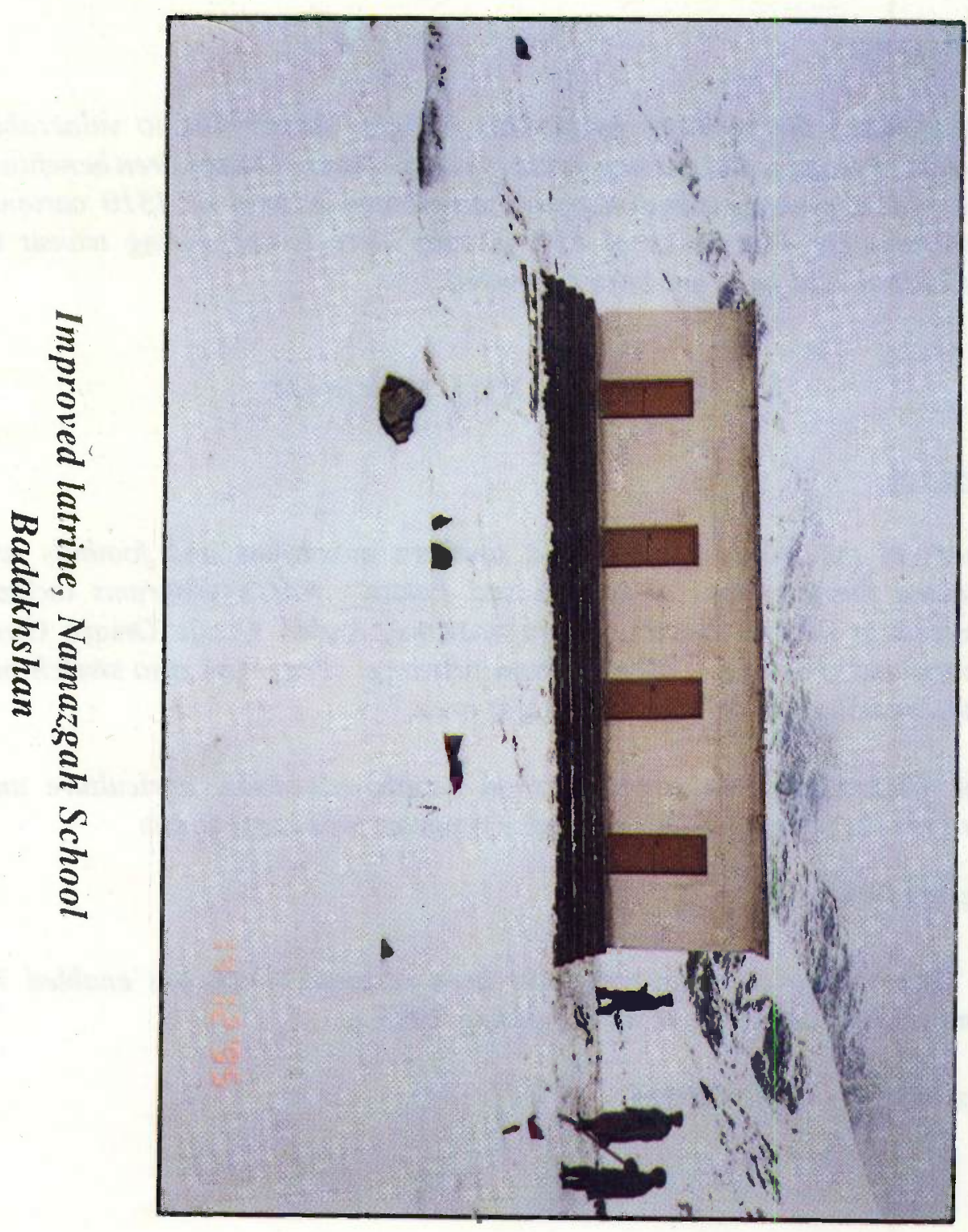




\section{Emergency}

UD donated the high energy biscuits BP5 for distribution to vulnerable groups. Pregnant and nursing mothers and malnourished children benefitted this aid. Eleven distribution points distributed a total of 1310 cartons. Unfortunately 40 cartons of BP5 biscuits were looted during transit to Badakshan and have not been recovered.

\section{GHAZNI/PAKTIA PROGRAM}

\section{General}

South of the Hindu Kush in the southern mountains and foothills are situated the provinces of Ghazni and Paktia. NAC's programs include projects in Zurmat district, Paktia province, Andar, Qwaja Omari, Giro, Aband and Ghazni city all in Ghazni province. Programs also stretch out into Jagathu district in the Hazarajat area.

The Ghazni program emphasizes on health, education, agriculture and women. In December an emergency program was carried out.

Agriculture

In Zurmat district 50 karezes have been restored which has enabled 72 families to return to their homes during 1995.

Donor: $\quad$ UNHCR/FM 
Ghazni/Paktia \& NAC Projects

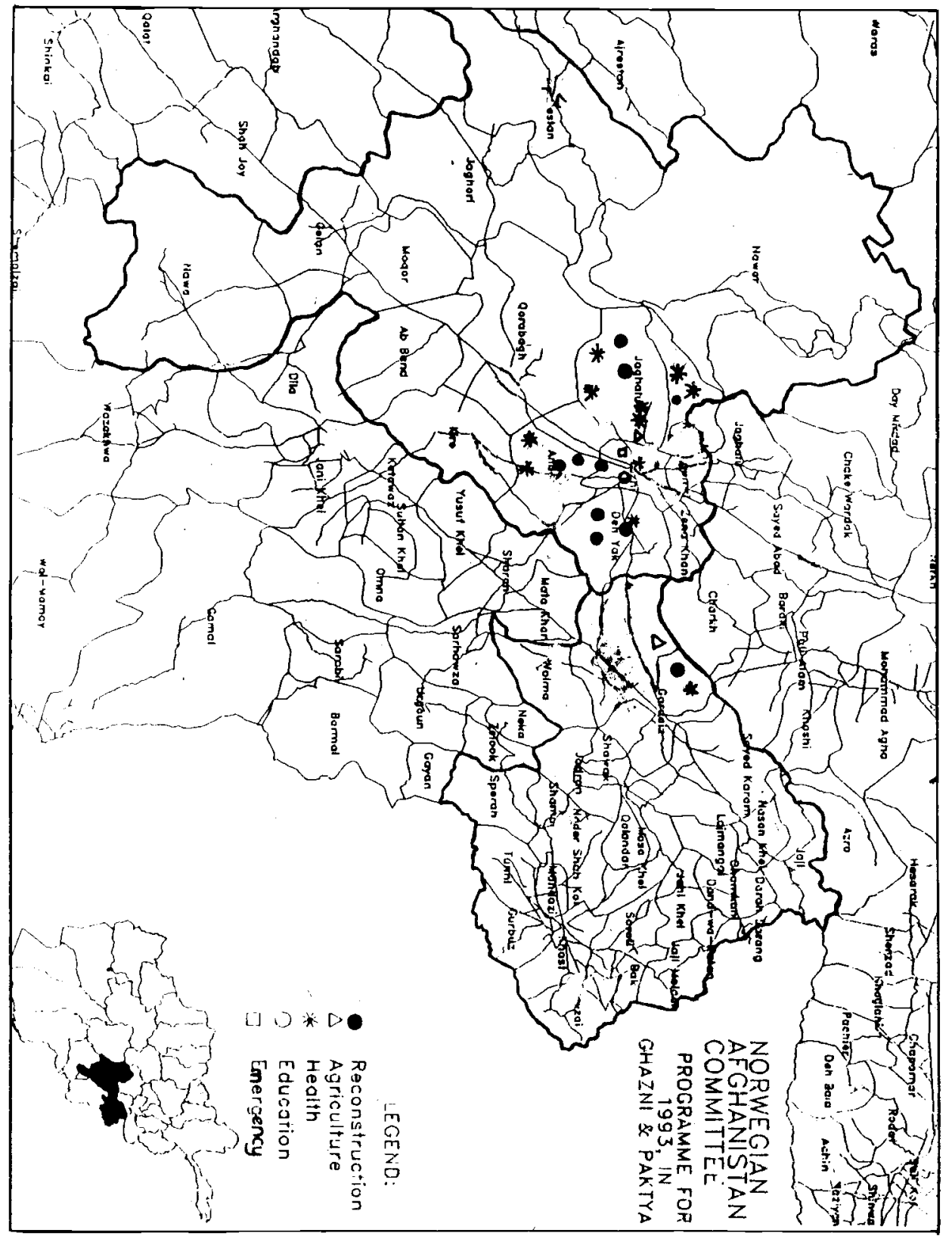


An improved wheat seed multiplication project was planned with FAO/NAC unfortunately the wheat seeds and fertilizer received from FAO were looted on its way to Ghazni and the planned project failed. NAC bought some improved wheat seeds from SAC and some minor plots were cultivated.

The Dawlat Khan nursery was closed down in August due to poor site and plant conditions.

\section{Education}

\section{School Support}

NAC has paid the running cost of 16 schools in Andar district in 1995 and one school in Ramak has been supported from August 1995 to December 1996. Running costs include payment of salary for the staff and provision of text books and stationery expenses.

\section{School Construction}

Six schools, comprising eight classrooms and four administration rooms have been constructed and one school has been repaired.

$\begin{array}{lllll}\text { School } & \text { Type } & \text { District } & \text { Work } & \text { Donor } \\ \text { Sarab } & \begin{array}{l}\text { Girls } \\ \text { Middile }\end{array} & \text { Jagathu } & \text { Recon } & \text { NORAD/WFP } \\ \text { Gulbori } & \text { Secondary } & \text { Khoigiant } & \text { Recon } & \text { NORAD/WFP } \\ \text { Kehak } & \text { Primary } & \text { Jagainu } & \text { Recon } & \text { FM/WFP }\end{array}$




\begin{tabular}{lllll}
\multicolumn{2}{l}{ Qal $\mathrm{i}$ Sardar Second } & Andar & Recon & NORAD \\
Sarde & Middle & Andar & Recon & NORAD \\
Ramak & Secondary & Ramak & Recon & FM \\
Tamir & High & Zurmat & Repair & FM/WFP
\end{tabular}

\section{Teacher Training Project}

To find qualified teachers in Ghazni and Paktia is a problem. To improve the teaching standards NAC employed three teach trainers to run different courses for local teachers. In 1995 four courses of four weeks duration were conducted in four different villages. Course' content included mathematics, chemistry, biology, physics, pedagogical methods and problem solving. A total of 88 teachers completed the course. After completion of the courses the teacher trainers visited the schools to monitor and evaluate the work of the teachers and of the course content.

\section{Health}

\section{Clinics}

Barakat clinic, Qwaia Omari district, Ghazni province, Khogiani ciinic. Jagatnu distric,, Hazarajat area ana Zurmat clinic, Zurmat district, Paktia province have been supported by NAC for medicai equipment, medicine and running costs during 1995.

Donor: $\quad F M$ 


\section{Chardewal Hospital}

The hospital, situated in Andar district, Ghazni province has been funded by NORAD since 1990. The hospital represents the only reliable medical service in the whole region it employs 4 MD doctors, two of whom are female, total number of staff is 43. Approximately 6,524 patients were treated in the hospital during 1995.

Malaria Prevention Program

To aid MSF's malaria prevention program NAC provided transportation costs and administered the selling of bed nets.

\section{Vaccination}

This program is an NAC/UNICEF initiative. UNICEF provides staff salaries, vaccines, syringes and storage equipment. NAC is responsible for the administration and transportation costs and is responsible for the vaccination program in Ghazni city, Andar, Aband, Giro, Jagathu and Qwaja Omari districts. Ten qualified vaccinators and eight assistants are presently working in the program. Women and children are targeted to be vaccinated against $T B$, diphtheria, whooping cough, tetanus and poliomyelitis. 


\section{Pictures}

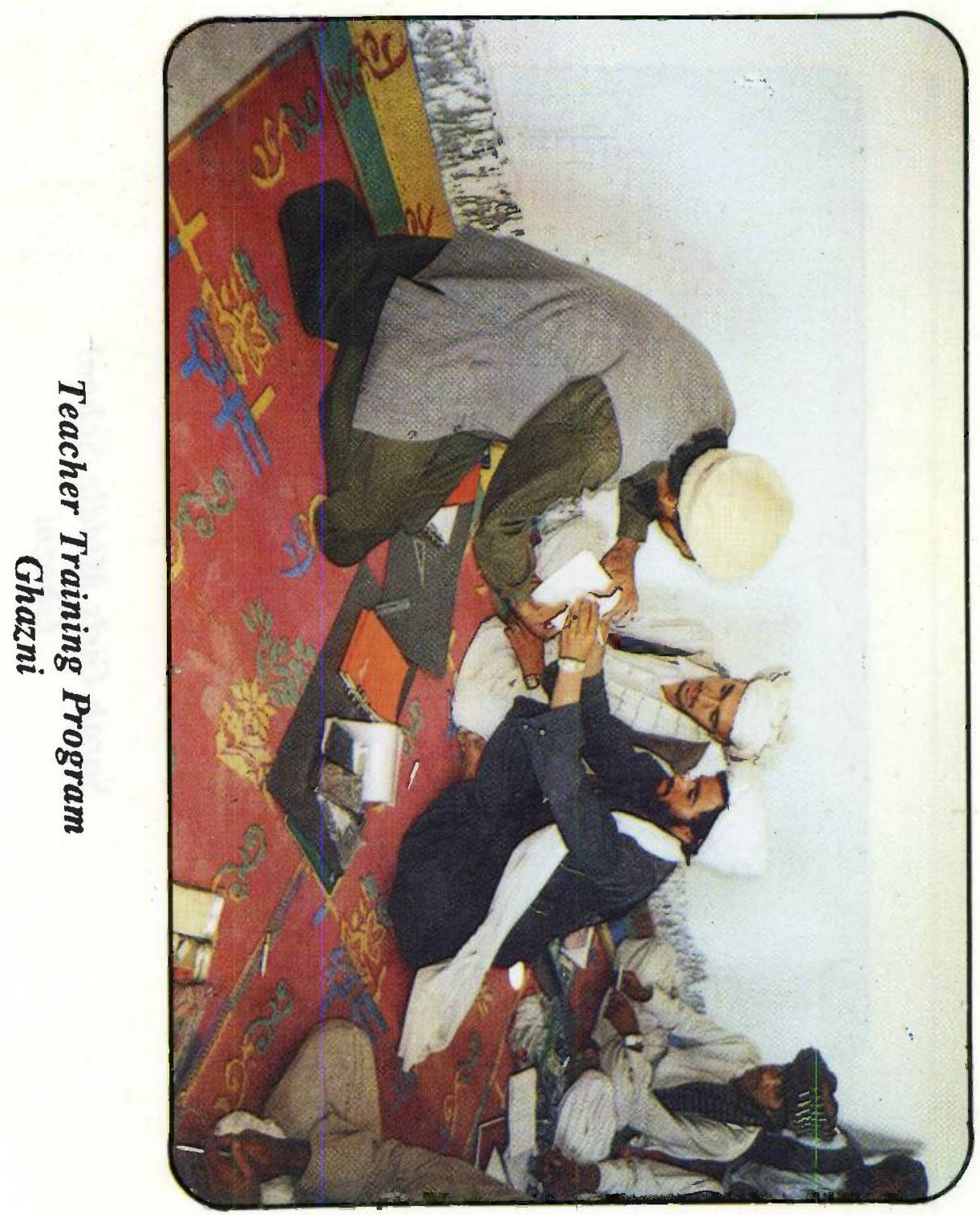




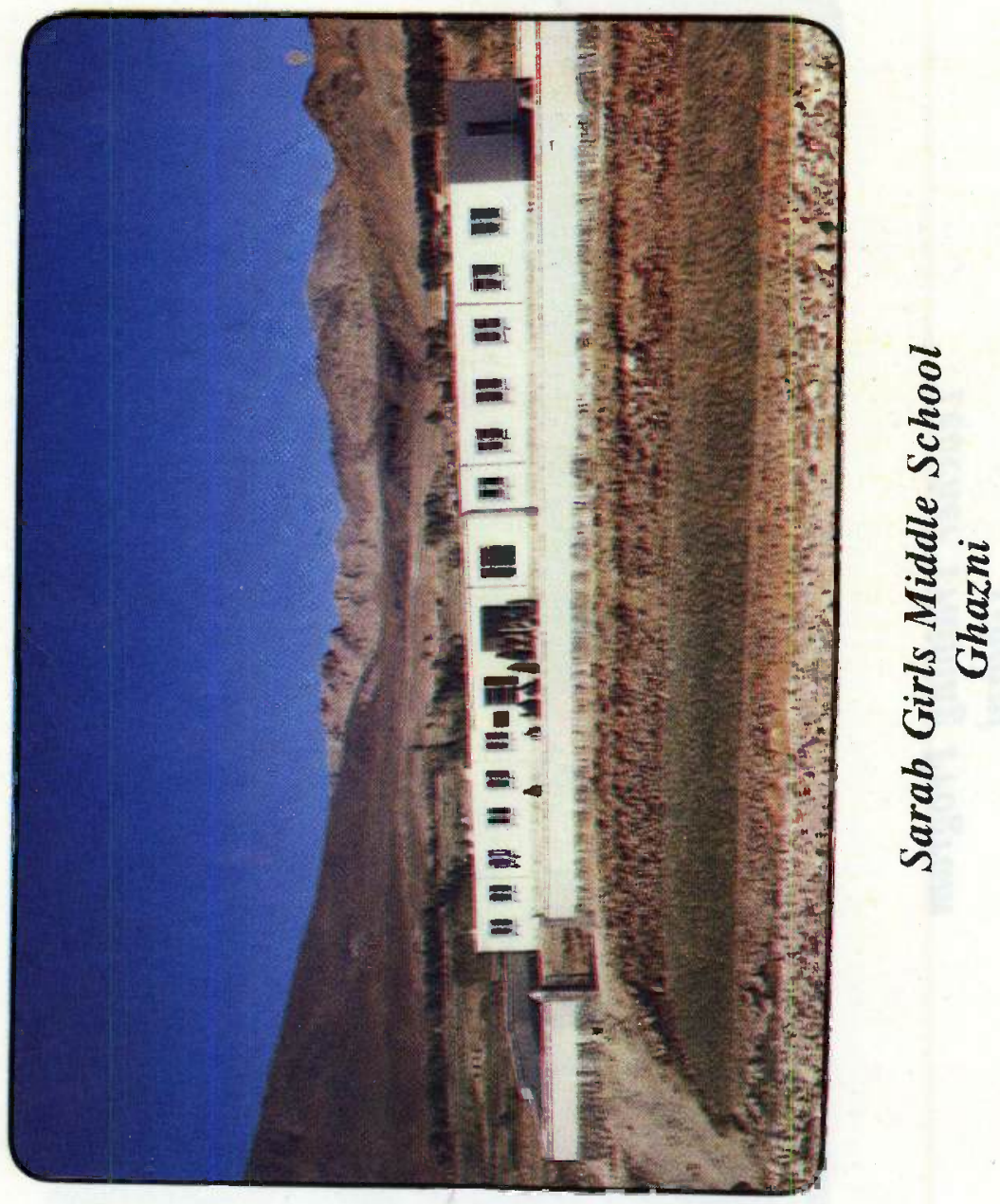




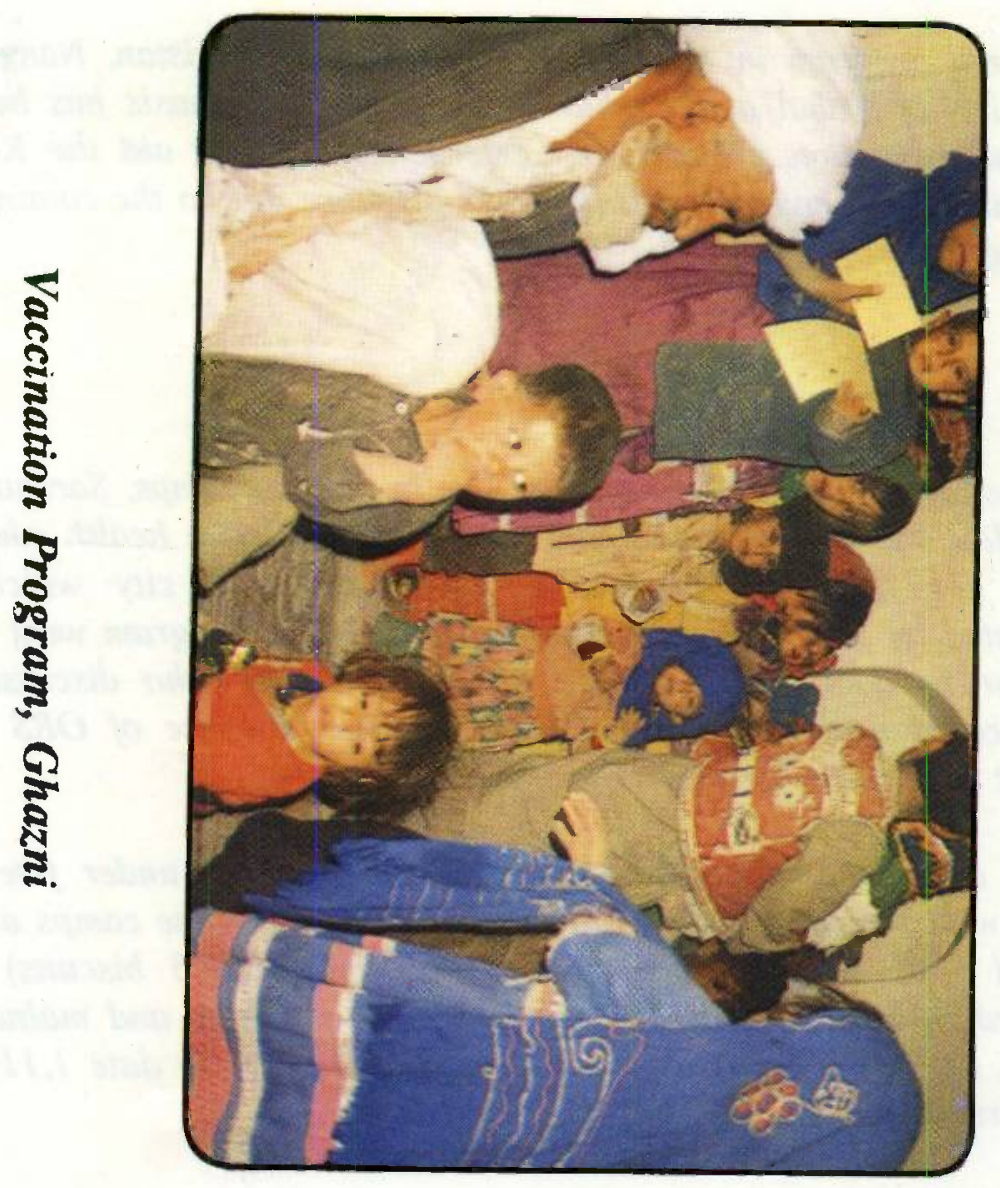




\section{EASTERN PROGRAM}

\section{General}

The Eastern program in 1995 covered projects in Nuristan, Nangrahar, the outskirts of Kabul and Peshawar. The main emphasis has been on health and education projects and emergency work to aid the Kabuli's who continued to emigrate to Nangrahar province due to the continuation of fighting in Kabul.

\section{Health}

In Nangrahar the internally displaced live in the two camps, Sarshahi and New Hadda and also in Jalalabad city. NAC funded a health education program for displaced people in the camps and city which was implemented by ERU (Emergency Relief Unit). The program went tent to tent, door to door, using female health educators who discussed the importance of using safe water, basic hygiene, the use of ORS in the treatment of diarrhoea etc.

Concern about the vulnerable status of the children under five years together with pregnant and lactating mothers living in the camps and city prompted NAC to donate emergency food items (BPS biscuits) to be distributed through the ERU health education program and malnutrition center in the city. 1,326 cartons were provided and to date 1,110 have been distributed. 
Eastern Zone \& NAC Projects

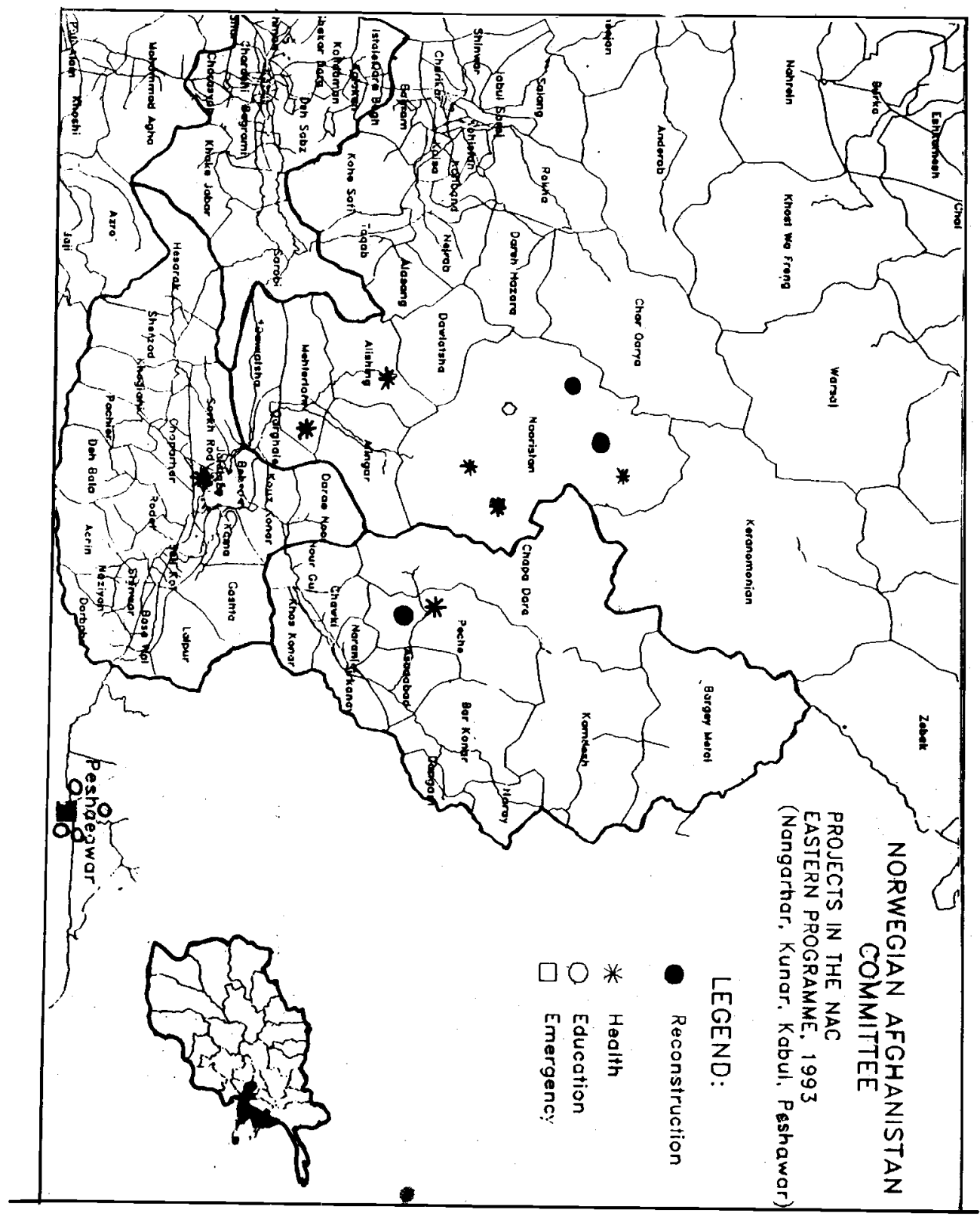




\section{UMCA Clinic}

UMCA (United Medical Center for Afghans) is an Afghan NGO, running a three component project comprising of dai-training (the training of woinen to aid the safe delivery of pregnant women without medical aid), literacy and mother and child clinic. NAC supported the training section while UMCA supported the $\mathrm{MCH}$ component. Forty five illiterate women were trained as "dais" and they also learned the basics of reading and writing.

\section{DR AFZAL'S Clinic, Keigal}

The clinic is located in central Nuristan. A qualified MD doctor, $x$-ray and laboratory technician and a female health educator/dai trainer work in the clinic. The clinic provides $O P D$, minor surgery, laboratory examination and dental extraction services. Approximately 15/20 patients are treated in the clinic daily.

\section{Shailam Clinic}

This is a small sub-clinic run by a mid level health worker under the supervision of Dr Afzal in a village of Pech district. The clinic provides basic medical and dental services to the local population.

\section{Khodaidad Dental Clinic}

The clinic is located in Aranz in Nuristan. The clinic provides primary dental services to the local population. 


\section{Nuristan Dai Training Program}

$N A C$ conducted three short term dai training courses in three villages, Muldesh, Kundkelay and Kaigal. Each course lasted for one month, or forty hours. A total of thirty women were trained in "birth attendance".

\section{Paghman (Latife) Dental Clinic}

NAC has supported the Paghman dental clinic since 1991. Due to the continuing of fighting in Kabul city people continue to attend the clinic for dental and medical care. ICRC is providing medicines to the clinic.

\section{Vocational Training}

Aranz village, Nuristan, became the first village to start a tailoring project for women funded by $N A C$. Two female trainers will implement a four month tailoring course for ten female trainees. Following the completion of the course the tailors will be subsidized for a further two months for the purchase of cloth etc and from then on will be self sufficient.

\section{Reconstruction}

\section{Aranz School, Nuristan}

An eight room school construction to be built in traditional masonry by the Aranz Shura will receive financial support during 1995 and 1996.

Donors for the Eastern programs were: NORAD, FM, UNICEF 


\section{Vocational Support}

Social and Humanitarian Assistance Committee for Afghans

SHACA is an organization working for female education and computer technology. A donation from NAC supplied a computer, monitor, printer etc for this program.

\section{Nasima Shaheed High School}

Nasima Shaheed High School is based in Khewa Refugee camp in Peshawar. Stationery for pupil use was provided during 1995.

\section{Amani Secondary School and Training Center}

A one time donation of support to the tailoring section of the training center was made during 1995.

\section{Female programs funded by NORAD/FOKUS}

Female programs funded by NORAD/FOKUS have been implemented in Ghazni, Eastern and Peshawar areas. The responsibility for these programs have been divided between the Ghazni and Eastern program managers and the education officer in'Peshawar.

The programs are as follows:

\section{Ghazni}

\section{Female Literacy Courses}

These courses have been conducted in Jagathu, Khwaja Omari and Ghazni city. The courses were initiated for the adult women but unfortunately they did not attend. Three hundred young girls and women taught by fifteen 
women teachers attended the courses and learned basic writing and reading.

\section{Dai Training Courses}

110 women from eleven villages have been trained as dai's "birth attendants".

\section{Mobile Female Clinic}

One female doctor and one assistant working in Ghazni city have been employed to attend women in Khwaja Omari district on a weekly basis.

\section{Eastern}

\section{Laghman Mother and Child Health Clinic}

UMCA (United Medical Center for Afghans) implements the running of the clinic in Mehterlam, center of Laghman province. Scarcity of health facilities for women caused problems for the females to receive medical aid. To help alleviate this problem a female doctor, nurse and pharmacist have been funded to work in the clinic.

\section{Laghman - Dai Training}

Thirty women were trained in "birth attendance" by SHEFA (Social Assistance and Health Education for Afghans). 


\section{Peshawar}

\section{Astrid Morken School}

The Astrid Morken school is located in an Afghan colony in Peshawar, and serves many of the refugee families living in the area. The school has 419 pupils, (287 girls, 132 boys), divided into 13 classes ranging from Ist - 6th grade. 20 teachers are working in the school. As well as providing financial aid the school has been supplied with educational materials and equipment.

\section{Bibi Aisha High School}

The Bibi Aisha High School is mainly for girls but due to the lack of schools for boys a small number of boys attend the school, 489 girls, 124 boys). A total of 650 pupils divided into 26 classes are taught by 43 teachers.

\section{Ummahat-ul-Momineen University}

In February 1990 the Ummahat-ul-Momineen University was created. It was the only university level institution open for Afghan refugees in Pakistan. In 1995600 female students registered at the University in the five different faculties: medicine, social science, law, education and literature. Funding had been agreed for the year but due to poor accounting and management systems funding was temporarily suspended. Analysis of the medical and social science faculties took place during the autumn of 1995, and following an evaluation of the accounting and management systems it is hoped to recommence funding. 


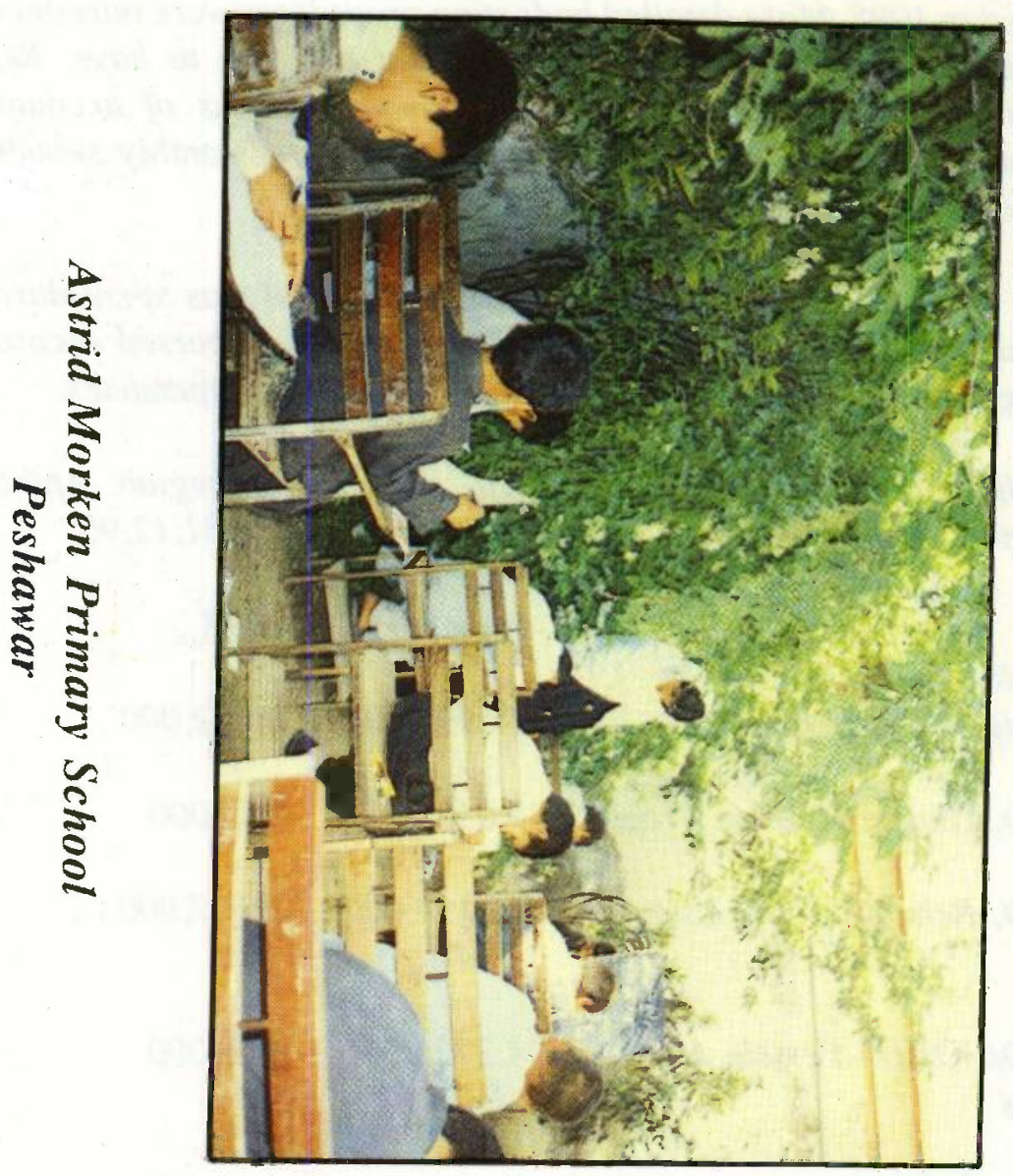




\section{Accounting \& Budget}

The Norwegian Afghanistan Committee central office Peshawar's computerized accounting system that has been used in 1994, was furthor developed in 1995. More detailed budgeting procedures were introduced and was detailed enough to give the information we wish to have. Regional offices inside Afghanistan are keeping complete books of accounts and financial reports, and the required information are monthly submitted to central office Peshawar.

Amount of $N k r .10 .880$. including donation in kind was spent during the financial year ended 31.12.95. All funds have been disbursed according to the budget and presupposition. For more details see Appendixes.

The following were the funds spent by the Norwegian Afghanistan Committee, Peshawar during the financial year ended 31.12.95.

Royal Norwegian Ministry

Rupees NOK.

of Foreign Affairs, projects

$15,995,000 \quad 3,212,000$

NORAD, Ghazni Medical Project

$4,058,000 \quad 815,000$

NORAD, Rehabilitation, Asia

$10,194,000 \quad 2,047,000$

Grant

NORAD/FOKUS Female Joint

Projects

$4,272,000 \quad 858,000$

Operation Workday, Education project

$2,364,000 \quad 475,000$ 
SCA, Construction Project

UNHCR, Irrigation Project

UNICEF, Health Project

-Cash

-in kinds

WFP, wheat for food and work, -in kinds

Sector_wise disbursement

Administration Peshawar

Health projects

Agriculture projects

Reconstruction/Irrigation

Education projects

Emergency Aid Projects
$3,266,000 \quad 656,000$

$1,856,000 \quad 373,000$

$526,000 \quad 105,500$

$1,073,000 \quad 215,500$

$10,572,000 \quad 2,123,000$

$54,176,000 \quad 10,880,000$

\begin{tabular}{|c|c|}
\hline Rupees & NOK \\
\hline $3,387,000$ & $\overline{681,000}$ \\
\hline $11,439,000$ & $2,297,000$ \\
\hline 362,000 & 73,000 \\
\hline $29,123,000$ & $5,848,000$ \\
\hline $8,217,000$ & $1,650,000$ \\
\hline $1,648,000$ & 331,000 \\
\hline $54,176,000$ & $10,880,000$ \\
\hline
\end{tabular}


Area_wise disbursements

Head office Peshawar

Eastern Program

Ghazni/Paktia Program

Badakhshan Program
Rupees $\quad$ NOK

$3,387,000 \quad 681,000$

$9,346,000 \quad 1,877,000$

$21,271,000 \quad 4,271,000$

$20,172,000 \quad 4,051,000$

$54,176,000 \quad 10,880,000$ 


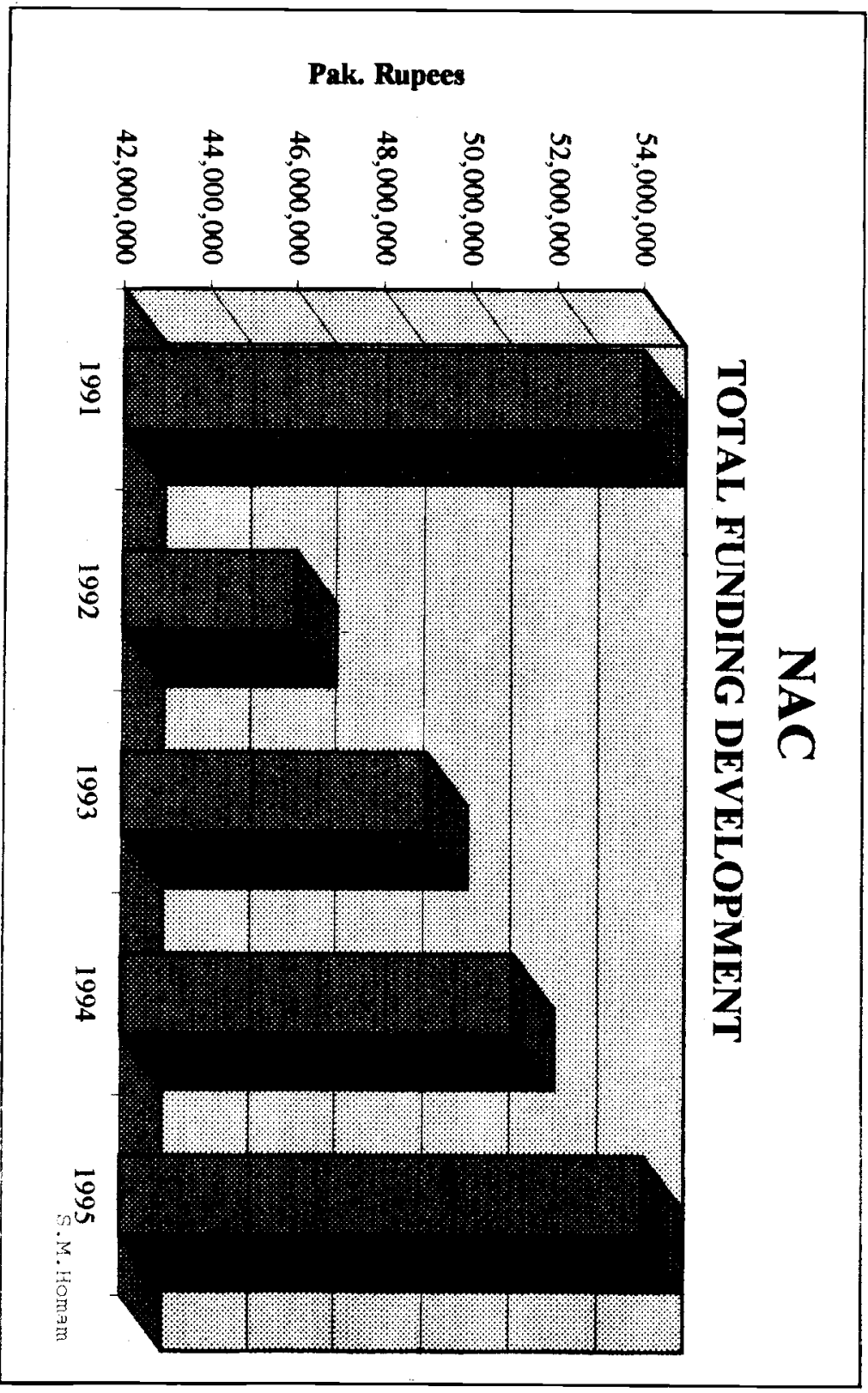




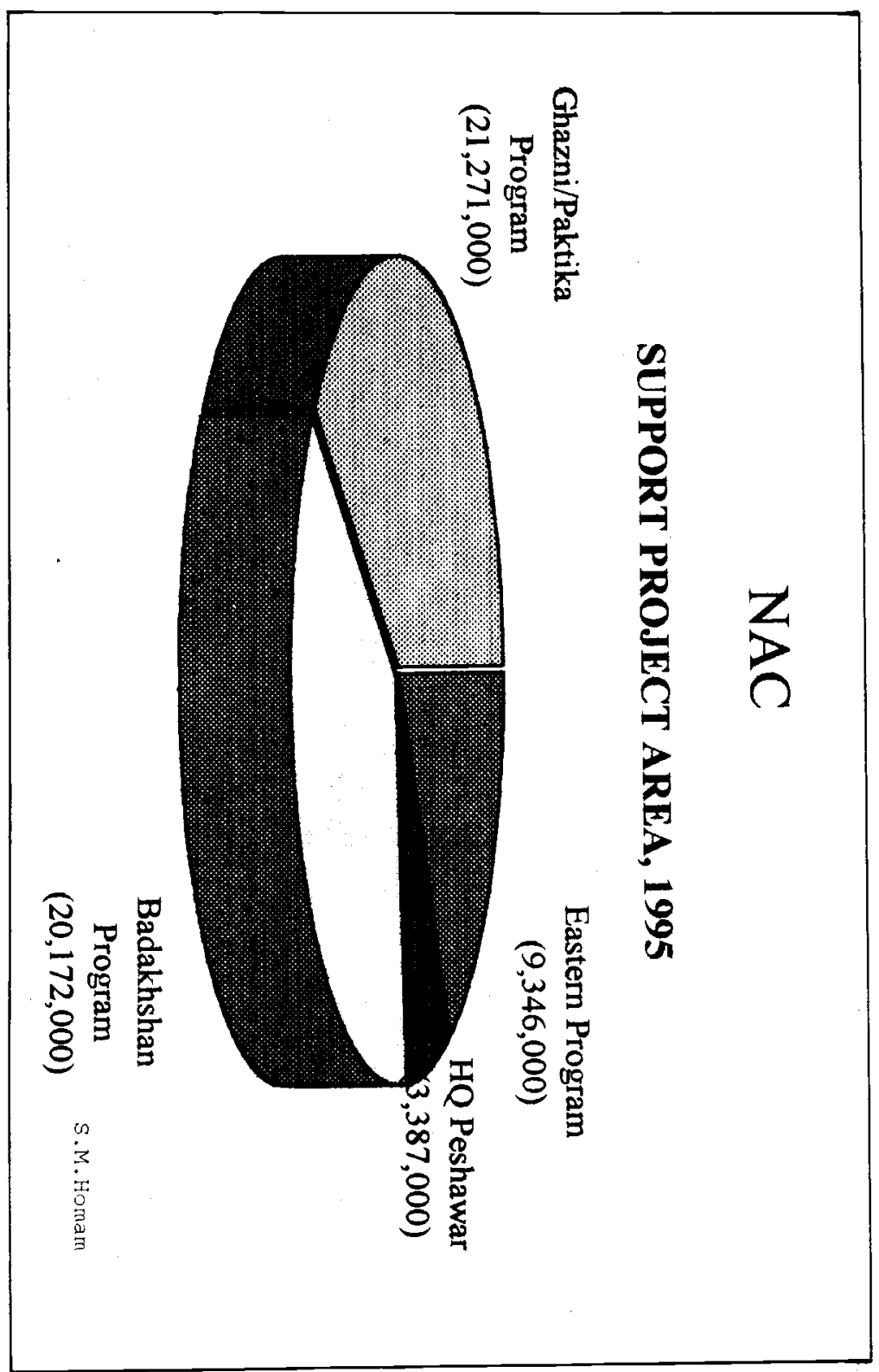




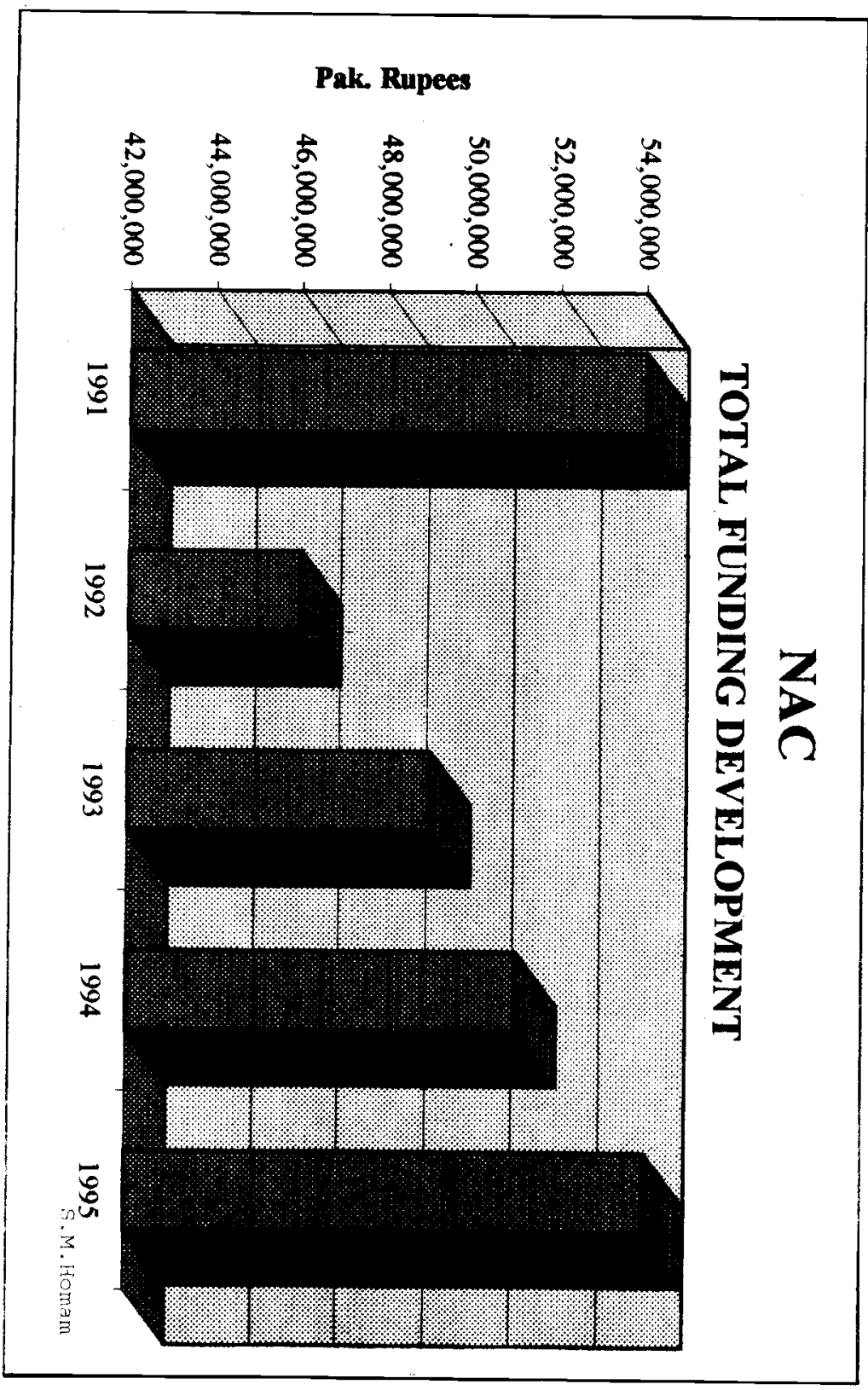




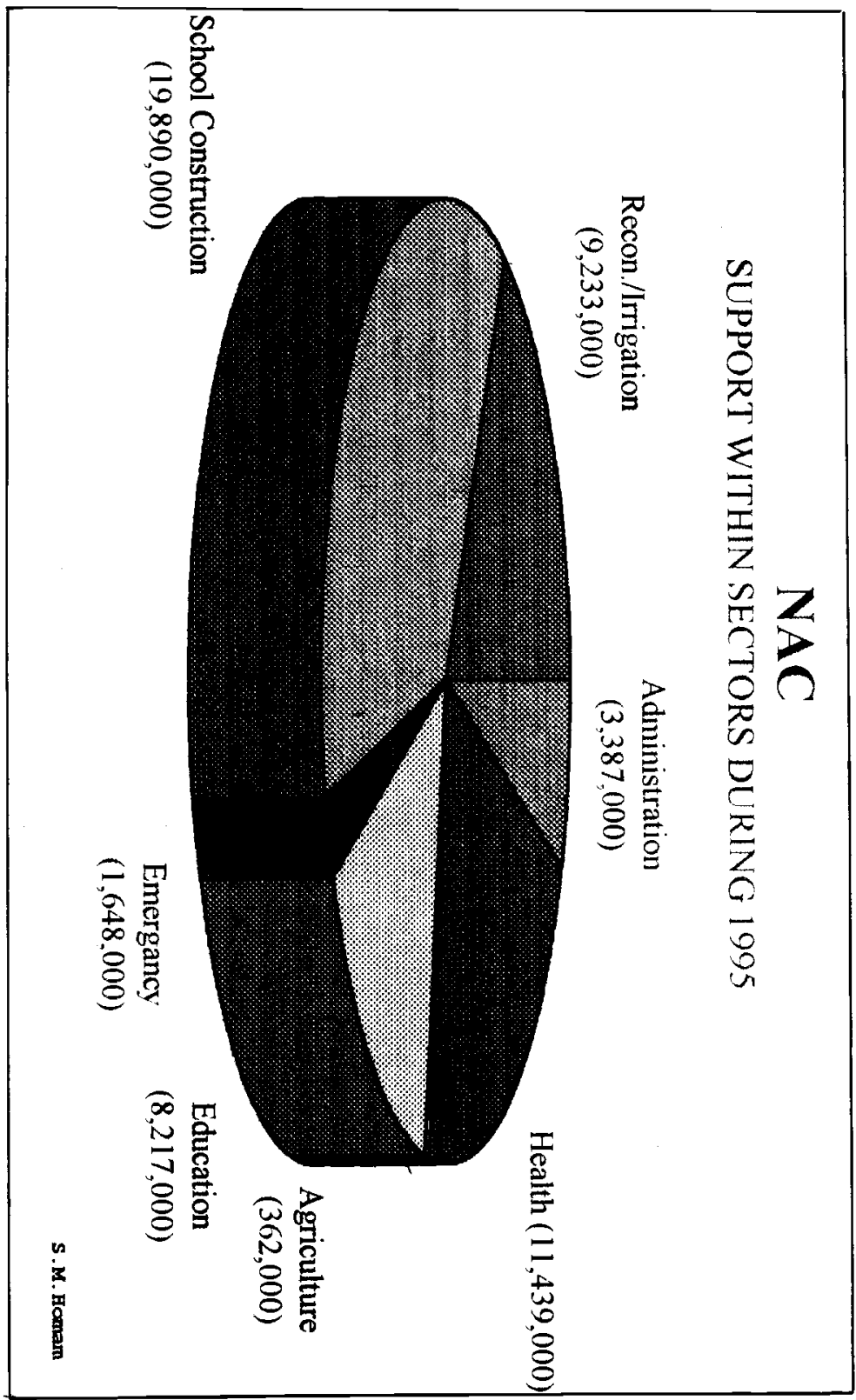


Annex 2

\section{List of Abbreviations}

NAC Norwegian Afghanistan Committee

SCA Swedish Committee for Afghanistan

UNHCR United Nations High Commissioer for Afghan Refugees

ERU Emergency Relief Unit

$A C B A R \quad$ Coordination body for organisataions working in Afghanistan.

MADERA European organization working with integrated rural development in Afghanistan.

NORAD Norwegian Agency for Development Cooperation.

TV-

Campaign

Annual collection among the public in Norway for assistance to projects in development countries.

Operation

"a workday"

Annual activity in Norwegian schools to collect funds for education projects $i$ developing countries.

Minde School

School children from Minde School collect funds for Astrid Morken School in Peshawar. 
Midtun school

School children from Midtun School collect funds for Zakoory School in Ghazni.

VSF Vaccination Cold Chain Facility/Center

TBA Traditional Birth Attendat also called Dai

WFP United Nations world food program

Edit \& Enquiry

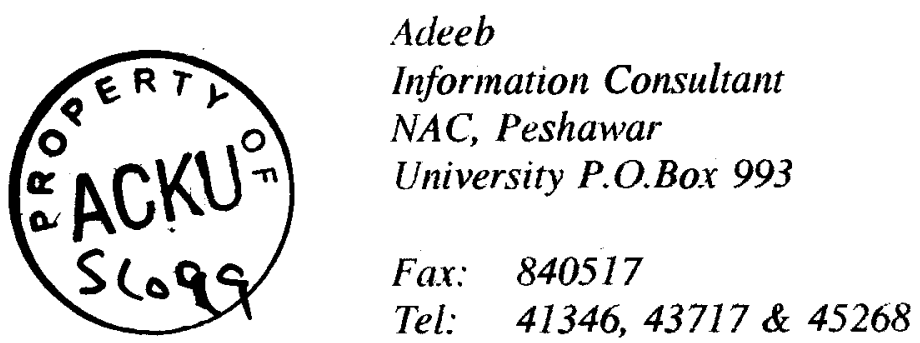




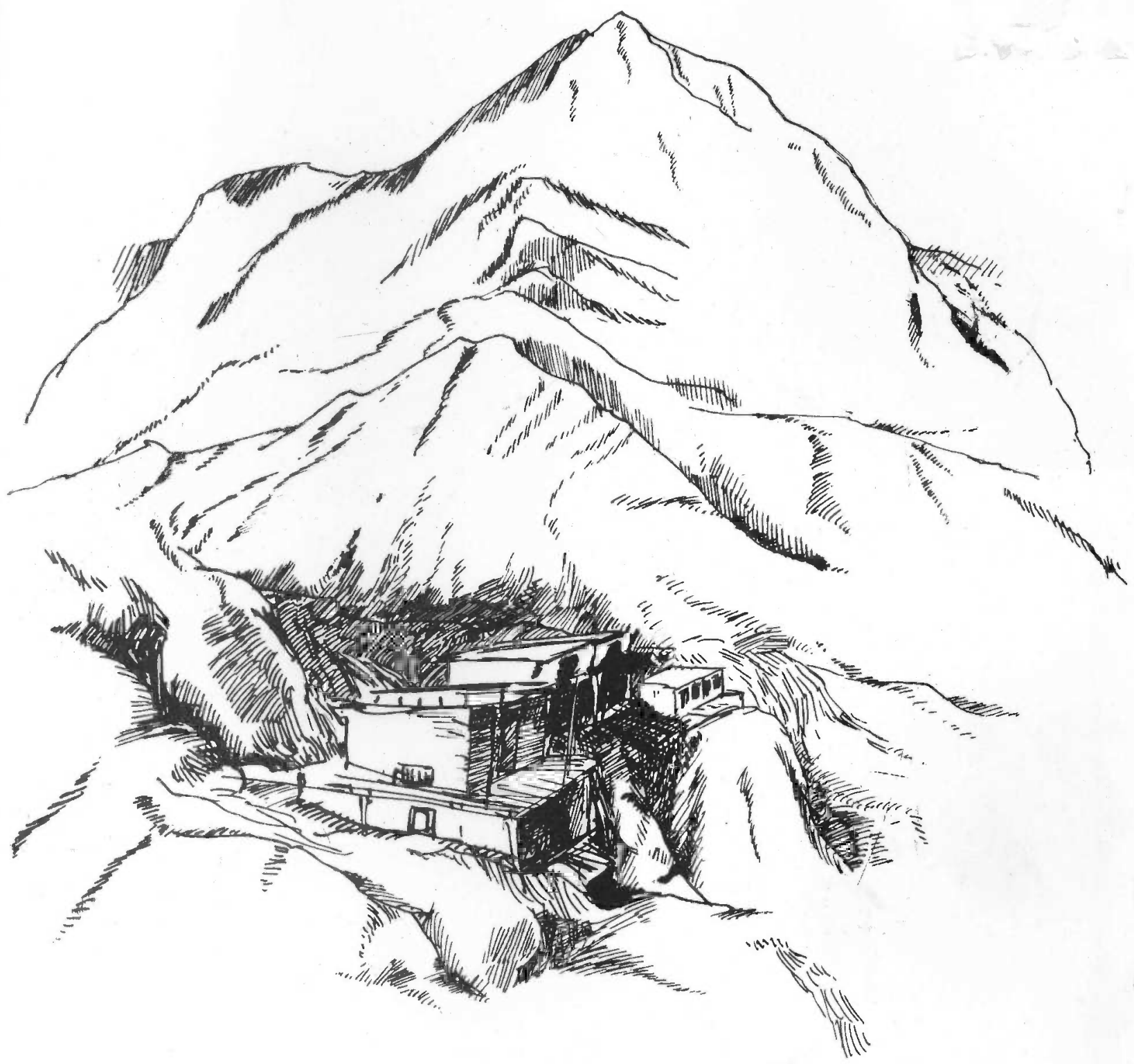

PRINTOGRAPH 211513 - Pesh 